\title{
A CONSTRUÇÃO OCIDENTAL DO ORIENTE MÉDIO COMO INSTRUMENTALIZAÇÃO DAS RELAÇÕES INTERNACIONAIS
}

\author{
WESTERN CONSTRUCTION OF THE MIDDLE EAST \\ AS INSTRUMENTALIZATION OF INTERNATIONAL \\ RELATIONS
}

Renatho Costa*

\begin{abstract}
Resumo: O presente artigo analisa a importância da região conhecida por Oriente Médio para a sedimentação da perspectiva estadocêntrica ocidental das Relações Internacionais. Para tanto, discute o processo que levou o Império Otomano à fragmentação e sua posterior divisão em Estados sob a égide das potências europeias que instituíram o sistema de Mandatos na região. Ainda, questiona como as relações de poder foram construídas no Oriente Médio no intuito de subsidiarem o modelo vestefaliano e reinante nas Relações Internacionais. Por fim, aborda qual o efeito da criação do Estado de Israel e de novos atores não-estatais (organizações islamistas) para a (des) estabilização da região e potencialização dos conflitos geopolíticos.
\end{abstract}

Palavras-chave: Oriente Médio, Relações Internacionais, Potências Ocidentais, Islã, Sistema Internacional.

\footnotetext{
*Bacharel em Relações Internacionais (FASM-SP), Mestre e Doutor em História Social (FFLCH-USP). Professor de Relações Internacionais na Universidade Federal do Pampa (UNIPAMPA), Santana do Livramento, Rio Grande do Sul, Brasil. Coordenador do Grupo de Análise Estratégica - Oriente Médio e África Muçulmana (GAE-OMAM).

E-mail: renathocosta@unipampa.edu.br
} 


\begin{abstract}
This article analyses the importance of the region known as Middle East to the sedimentation of Western state-centric perspective of International Relations. To do so, it discusses the process that led the fragmentation of the Ottoman Empire and its subsequent division into states under the aegis of the European powers that established the Mandate system in the region. Furthermore, it questions how power relations were built in the Middle East in order to assist the Westphalian reigning model in International Relations. Finally, it debates what was the effect of the creation of the State of Israel and of new non-state actors (Islamist organisations) in order to (de)stabilize the region and potentiate geopolitical conflicts.
\end{abstract}

Keywords: Middle East, International Relations, West Powers, Islam, International System.

O estudo da estrutura do sistema internacional é objeto primordial das Relações Internacionais (RI). Partindo do pressuposto de que a polaridade do sistema - multipolar, bipolar, unipolar, uni-multipolar, dentre outras possibilidades - influi diretamente na atuação dos atores, as Escolas de RI construíram teorizações que ratificaram a forma com que se dá o processo de submissão e/ou sublevação deles.

Parte substancial da forma com que as RI são percebidas por seus teorizadores encontra respaldo em eventos históricos que foram assimilados por suas Escolas no intuito de ratificar um modelo de sistema internacional composto, basicamente, por Estados. Nesse sentido, a Paz de Vestefália (1648) é tida como um paradigma de difícil transposição, pois a preservação da soberania estatal tornou-se condição sine qua non neste modelo ${ }^{1}$. Para as RI, o estadocentrismo configura-se no referencial primordial para se entender e analisar as relações entre os atores internacionais. Evidentemente que a partir do final do século XX as Escolas construtivistas e pós-modernas passaram a colocar em xeque não somente as questões epistêmicas, como ontológicas das RI, no entanto, o mainstream continua considerando o Estado como o ator preponderante na estrutura do sistema internacional.

Assim, o objetivo deste artigo é analisar a razão pela qual as potências europeias do século XIX - que mantiveram seu status quo até a II Guerra Mundial - optaram por desconstruir o Império Otomano e reestruturá-lo a partir do modelo vestefaliano, contudo, preservando a supremacia ocidental na região conhecida por Oriente Médio. Ainda, demonstrar que na tentativa de reproduzir um sistema semelhante ao vivenciado pelos Estados europeus, a assimilação não se deu de modo natural e a região se transformou numa zona de tensão constante. Ou seja, questiona-se a aplicabilidade do modelo estadocêntrico para os Estados de maioria islâmica do Oriente Médio e como 
as RI tratam desta questão.

De certo modo, a partir do tratado secreto Sykes-Picot (1916), assinado por ingleses e franceses no intuito de dividir o espólio otomano, o Oriente Médio ganhou importância substancial para as Relações Internacionais. Tal afirmação pode ser constatada não apenas ao analisar a região com base em modelos teóricos pré-estabelecidos, mas também na aplicação de formulações geopolíticas que busquem entender as constantes transformações que a região perpassa.

Assim, este artigo trata, inicialmente, da maneira com que as potências europeias do século XIX efetivaram a desconstrução do Império Otomano e criaram um Oriente Médio "aos moldes do sistema vestefaliano". Sublinhase, aqui, o fato de que o processo que levou ao fim do Império também contou com fatores internos, os quais são tratados neste artigo. Na sequência buscase discutir como o surgimento do Estado de Israel (1948) e a bipolaridade do sistema internacional durante a Guerra Fria influíram no tensionamento regional. Por fim, a situação do Oriente Médio é analisada a partir da inserção de outros atores não-estatais (islamistas) e o quanto este novo elemento contribuiu para a instabilidade da região.

\section{OS ÚLTIMOS DIAS DO ÚLTIMO IMPÉRIO ISLÂMICO}

O Império Otomano (1299-1923) - que suprimiu a primazia árabe nos desígnios do Islã -, em final do século XIX já se encontrava bastante fragilizado e sua unidade comprometida devido a ações externas e internas. Ainda que se considere que a unidade a partir da identidade islâmica se configurasse em um elemento distinto e emblemático, os atos promovidos pelos últimos sultões comprometeram de modo irreversível a estabilidade e manutenção da estrutura política imperial.

Nesse sentido, vários fatores contribuíram para o enfraquecimento do Império Otomano, no entanto, o tensionamento entre árabes e turcos pelo direito de conduzir a comunidade muçulmana apresenta-se como o elemento interno preponderante, haja vista afetar a questão da identidade e do direito de governar os muçulmanos. Como resultado deste embate, o nacionalismo árabe ganhara força junto aos opositores do Império e apresentava-se como solução para suceder o modelo colocado em prática pelo sultão otomano, no entanto, sem conseguir alcançar os resultados esperados.

Durante o sultanato de Abdülhamid II (1876-1909) houve a promulgação da Constituição para o Império, em 1876, mas logo foi suspensa e o sultão passou a implementar sua política pan-islâmica. Percebendo a necessidade de arregimentar os árabes muçulmanos para o Império, mais que os turcos - que já possuíam ligação bastante forte devido à descendência étnica - Abdülhamid utilizou o pan-islamismo para refrear as forças nacionalistas árabes que ambicionavam a fragmentação do Império Otomano. Contudo, 
tratou-se de uma estratégia política que não alcançou o resultado esperado e fez com que o sultão partisse para uma ofensiva mais enfática contra os movimentos pan-arabistas.

No entanto, há de salientar que ao assumir o poder Abdülhamid deu continuidadeà política de modernização do Império que vinha sendo implantada por seus antecessores através do Tanzimat. Isso se deveu à preocupação do sultão frente à disparidade entre o desenvolvimento das potências ocidentais e o Império Otomano, assim, a europeização se configurava numa tentativa de equiparação ao potencial do Ocidente $^{2}$. Com isso, colocou-se em prática a modernização do sistema de Justiça e de Administração; a centralização do poder foi facilitada pelo uso do telégrafo e da construção de ferrovias; houve a repressão aos beduínos e apoio às colônias agrícolas; e, a criação de escolas primárias, secundárias e universidades ${ }^{3}$. Entretanto, apesar da imagem liberal do governo, a preservação da unidade imperial sob as mesmas bases era questionável. Ainda, a tolerância para com os não-muçulmanos mudara de face e o entendimento que perdurava era de que somente através da implementação de uma mudança radical seria possível manter unido o Império e evitar a ação das potências europeias.

O projeto de Abdülhamid era ambicioso, ele buscava aproximar-se do modelo ocidental para se proteger da ação das potências europeias. No entanto, também mantinha sua preocupação voltada para o mundo islâmico, e, para tanto, pretendia que o sultão tivesse seu status modificado e passasse a ser reconhecido como califa. Entendia, por conseguinte, que tal ato repercutiria diretamente no fortalecimento do Islã e, para tanto, não negava esforços ao expressar-se como o autêntico detentor das virtudes necessárias de um califa ${ }^{4}$.

Por sua vez, os movimentos contrários à proposta do sultão não mais podiam ser calados. Em grande parte porque a intelectualidade muçulmana já possuía veículos para manifestar suas inquietações e desejos. Jornais e livros eram publicados no Cairo, em Beirute e na Europa difundindo ideias de desaprovação ao projeto de Abdülhamid - a influência de ideologias europeias era flagrante nestas publicações. Alguns propunham que houvesse a transferência do sultanato para o Cairo e o califado para Meca. Dessa forma o Islã voltaria às mãos dos árabes, haja vista congraçarem a perspectiva de que os turcos, por mais que tenham se dedicado à fé islâmica, acabaram por desvirtuá-la. Uma segunda proposta também defendia que os poderes temporal e espiritual poderiam voltar a ser concentrados na figura do Califa - retomando à Meca -, aos xarifes de Meca. O ideário nacionalista também encontrava abrigo nas páginas das publicações.

Frente à instabilidade interna, a conclusão que certos pensadores chegavam era de que o Islã estava em decadência. Para tanto, apontavam para vários fatores históricos, mas, de acordo com Abd al-Rahman al-Kawakibi ${ }^{5}$ (1849-1903), era evidente que 
[...] o Islã decaiu por causa da inovação ilegal (bid'a), em particular da introdução de excessos místicos alheios ao seu espírito, e por causa da imitação (taqlid), da negação dos direitos da razão e do fracasso em distinguir o que é essencial do que não é [...] O Estado justo, em que os homens se realizam, é aquele em que o indivíduo é livre e serve livremente à comunidade, e em que o governo vigia essa liberdade, mas é ele próprio controlado pelo povo; isso é que é o verdadeiro Estado Islâmico ${ }^{6}$.

Retomando à questão da política nacionalista turca implementada por Abdülhamid; dentro do Império e mesmo na França e Itália, um grupo de oponentes ganhava a simpatia dos nacionalistas árabes - os Jovens Turcos. Eles atacavam veementemente o despotismo do sultão e clamavam pela volta do regime constitucional que havia sido extirpado. Com propostas que reforçavam o espírito de união dentro do Império, independentemente da religião confessa, representavam uma esperança de restauração do equilíbrio para os muçulmanos. Assim, através de uma grande revolta, em 1908, conseguiram depor o sultão e chegaram ao poder, entretanto, a realidade dos fatos falou mais alto do que a ideologia.

Os Jovens Turcos, para colocarem em vigor a Constituição, que era emblemática em sua proposta, deveriam partir do pressuposto de que todos os cidadãos do Império eram iguais e gozavam dos menos direitos e deveres; que as diferenças religiosas, mesmo entre muçulmanos e não-muçulmanos, não deveriam existir. Porém, não foi dessa maneira que ocorreu. Para a manutenção do Império, que também era parte integrante do projeto dos Jovens Turcos, houve a necessidade de preterir os demais cidadãos do Império em benefício dos turcos. Essa prática se fazia necessária por acreditar-se, mesmo que de maneira indireta, que a relação com o Império estaria mais enraizada no turco do que em outro cidadão qualquer. Também, para a manutenção do Império não poderiam abrir mão da centralização administrativa, o que ia de encontro à ambição das várias províncias que buscavam com veemência a autonomia.

Ao final do governo dos Jovens Turcos, em 1913, o Império estava bastante fragilizado e desacreditado devido à mudança radical pela qual as diretrizes governamentais sofreram e, naquela ocasião, a visão liberal do grupo se confundia com o antigo nacionalismo de Abdülhamid - tão contestado e renegado. Ziya Gökalp, ideólogo dos Jovens Turcos, procurou analisar onde o projeto político de seu grupo teria falhado.

O ponto de partida foi a idéia de que a única maneira de resolver o dilema inerente ao império era lhe impor um único sentimento nacional; mas aos poucos tornou- 
se claro que o sentimento nacional otomano não podia desempenhar esse papel, pois era demasiado fraco e artificial, e em última análise não se baseava em nada exceto na lealdade à família regente ${ }^{7}$.

No Líbano, por exemplo, onde ainda não havia uma leitura única acerca dos acontecimentos inerentes ao Império, a frustração com a mudança política dos Jovens Turcos serviu para reforçar um certo "nacionalismo libanês" que surgia. A grande maioria cristã, e parte dos sunitas que ora habitavam o Monte Líbano, convalescidos e frustrados pela mudança dos Jovens Turcos, convictamente assumiram que deveriam trabalhar em prol da independência através de quaisquer meios que fossem necessários. Questionava-se, somente, se a ajuda deveria vir da Europa, onde as potências facilmente se prontificariam a dar suporte militar; ou se a integração com a Síria, cujos laços históricos eram ressaltados, seria a melhor maneira de iniciar o movimento de independência.

A inquietação foi mantida até 1914, quando a I Guerra Mundial teve início e o Império Otomano assumiu o posicionamento que o levaria à ruína total. Aliado da Alemanha e do Império Austro-húngaro, logo suspendeu a semi-autonomia de algumas províncias. Em pouco tempo a situação socioeconômica da população sofreu um forte revés. Muitos habitantes da região foram obrigados a se alistar no exército otomano, enquanto outros passaram a desempenhar atividades estratégicas, como a derrubada de árvores para a construção da estrada de ferro, além de a construção de estradas de rodagem e campos de treinamento, ambos para fins militares ${ }^{8}$. De fato, tal ação demonstrava que o Império não mediria esforços para alcançar seu objetivo, que, naquele momento, se configurava na manutenção da unidade político-territorial.

\section{A ERA DOS TRATADOS E ACORDOS: A DIVISÃO DO MUNDO ÁRABE}

Enquanto os problemas internos dos otomanos apontavam para a necessidade de revisar sua estrutura político-administrativa, na Europa, a certeza de que o Império Otomano não manteria sua integridade territorial por muito mais tempo era notória; em vista disso, as potências procuravam estabelecer, rapidamente, acordos que lhes garantissem privilégios na região. Considerando o fato de que o modelo multipolar prevalecia na Europa desde 1815 (Congresso de Viena), e que havia a necessidade de as potências balancearem seu poder ${ }^{9}$, a ampliação da zona de influência se apresentava como uma necessidade vital. Agravada, ainda mais, pelo desequilíbrio gerado pela inserção da Alemanha - a partir de sua unificação, em 1871 - como potência. Assim, o Império Otomano se configurava numa zona de disputa 
por parte das potências europeias, devido, inclusive, à dificuldade dos sultões de controlarem seu território.

Frente a este cenário, em 1916, França e Grã-Bretanha assinaram um acordo secreto que passou a ser conhecido como Sykes-Picot ${ }^{10}$. O Acordo almejava contemplar os interesses das potências e cristalizar o poder que já era exercido de maneira indireta por elas. Com isso, determinavam-se duas formas de atuar na região: "diretamente" e através das "zonas de influência". Para que houvesse a anuência da Rússia no acordo, as regiões da Anatólia e Pérsia ficaram fora das negociações, sendo citadas como de administração internacional, conforme salienta o segundo parágrafo do acordo:

[.... that in the brown [na cor bege, no mapa] area there shall be established an international administration, the form of which is to be decided upon after consultation with Russia, and subsequently in consultation with the other Allies, and the representatives of the Shereef of Mecca ${ }^{11}$.

Evidenciava-se, desse modo, o interesse da Rússia em futuramente expandir seu território e/ou sua zona de influência assim que ocorresse a derrocada do Império Otomano.

\section{DIVISÃO DO ORIENTE MÉDIO - ACORDO SYKES-PICOT}

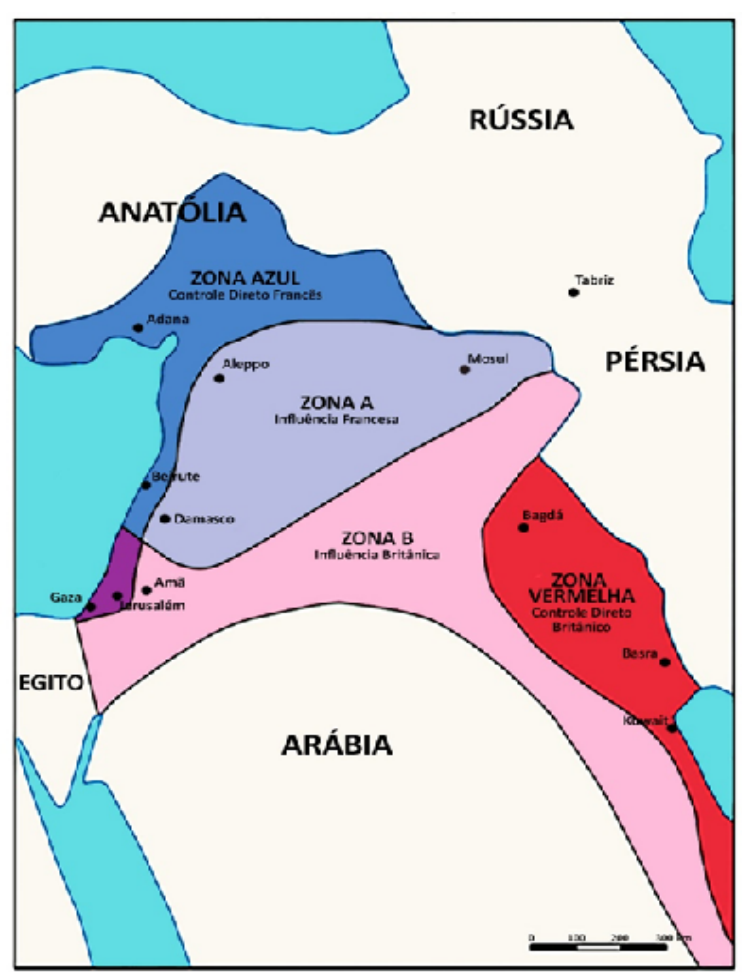

Fonte:Palestinian Academic Society for the Study of International Affairs (PASSIA) adaptado. 
A intenção das potências - França e Grã-Bretanha - de fragmentarem o poder na região do Oriente Médio era notória, haja vista esta estratégia contribuir para enfraquecer o sultão e mesmo os vínculos produzidos pela religião islâmica. Por mais que houvesse, e há, diferenciações entre os diversos segmentos do Islã, o receio de a ummah - comunidade islâmica - continuar integrada era algo latente e que deveria ser superado. Para isso, se fazia necessário satisfazer as lideranças locais que estavam alinhadas aos interesses britânico e francês. Desse modo, como parte do Sykes-Picot, os britânicos fizeram com que a região ora conhecida como Arábia Saudita ficasse fora da zona de atuação das potências devido, também, a acordos paralelos firmados com lideranças locais.

Apart from its agreement with France over the partition of the Arab provinces of the Ottoman Empire, Britain had made promises during the war to other parties concerning the same area. In central Arabia, there was a standing British alliance with Abdul-Aziz Ibn Saud, the Wahhabi Emir of Riyad who was subsequently to become the founder of the kingdom of Saudi Arabia. Wahhabism was a movement of militant Islamic religious revival which had appeared in central Arabia in the middle decades of the eighteenth century, and the house of Saud had been politically associated with it since that time. In conflict with this British-Saudi alliance was the wartime alliance reached between Britain and Sharif Husayn, the Emir of Mecca, who enjoyed a special Arab and Islamic prestige as a recognized descendant of the Prophet, and whose family were called the Hashemites ${ }^{12}$.

No entanto, conforme Salibi ${ }^{13}$ expõe, a divisão do Oriente Médio em cinco Estados artificiais não foi algo facilmente assimilado pelos árabes. Contudo, a relação de quatro deles - Síria, Transjordânia, Iraque e Palestina - em comparação ao Líbano foi diferenciada. Isso porque não havia uma proposta clara para os demais países recém-criados de se transformarem em estados independentes, haja vista, dentre eles, haver o forte ideal do nacionalismo árabe. No entanto, quando o Líbano despontou como um Estado independente e deslocou-se do restante da comunidade árabe, a repercussão por parte dos demais Estados foi bastante negativa. A aceitação de uma nacionalidade libanesa, acima da árabe era algo inconcebível para grande parte dos habitantes dos recém-formados Estados. Por sua vez, os muçulmanos que viviam no Líbano passaram a conviver com a forte tensão de como seriam tratados diante da nova situação que estavam assumindo. Em parte, esse receio advinha do forte apoio que a França estava dando à 
criação do Estado libanês nos moldes de Vestefália, mas sem a prerrogativa da soberania plena, como será exposto adiante.

Para que prevalecesse a nacionalidade libanesa acima de qualquer outra, e nenhuma forma de pressão por parte dos demais árabes a enfraquecesse, principalmente dos sírios, que nutriam uma ligação bastante próxima dos libaneses, um alto preço teve de ser pago, e

[...] this price was to be significantly heavier as the Maronites (que defendiam mais claramente a independência libanesa e criação de uma nacionalidade própria) had actively solicited the help of France to achieve their ends; even more so, because they had knowingly exhibited a marked insensitivity to Arab frustrations around then. In October 1918, when France forces landed in Beirut to put an end to the short-lived Arab government of Sharif Faysal (governante nomeado pelo sultão) there, Maronites and other Christians waving French flags had cheered their arrival at the port, hailing France as the "tender, loving mother" (Arabic, al-umm al-hanun) who was to be their saviour ${ }^{14}$.

Na Europa, as potências, além de utilizarem manobras políticas para exercerem seu domínio sobre o Oriente Médio, também criavam mecanismos para ampliar suas possessões na África e Ásia. E, com o intuito de angariar o apoio dos judeus para seu projeto nacional, a Grã-Bretanha passou a defender oficialmente a proposta de criação de um lar-nacional judaico na Palestina.

Contando com o aval da Coroa britânica, em 2 de novembro de 1917 houve a divulgação da Declaração Balfour, um documento polêmico, pois anunciava a intenção de criar um Estado sem que a comunidade árabe que habitava a região da Palestina fosse consultada. Nesse sentido, apesar de a proposta não ter um caráter inicial sectarista, haja vista declarar que "[...] o governo [britânico] via com bons olhos o estabelecimento de um lar nacional judeu na Palestina, contanto que isso não prejudicasse os direitos civis e religiosos dos outros habitantes do país [os palestinos]"15, o caminho que seguiu para ser implementado demonstrou a incompetência políticoadministrativa dos britânicos como mandatários da região da Palestina ou sua parcialidade ao tratar com judeus, em detrimentos dos palestinos. El-Alami entende que os britânicos, com seu jogo duplo, estivessem preocupados com os rumos que a I Guerra Mundial poderia tomar e, por isso, tentavam atender a todos, no entanto, expressa que "[...] no começo de um século que as populações nativas estavam começando a se libertar da opressão da influência colonial estrangeira, estava sendo incubado o esquema mais calculado para o estabelecimento artificial de uma população [judaica] que chegava [à 
Palestina]"16.

O posicionamento assumido pelo governo britânico em prol do estabelecimento de um lar-nacional judaico na Palestina teve repercussão em graus variáveis nas diversas localidades do Oriente Médio, no entanto os árabes viram com muita preocupação tal posicionamento imperialista. Inclusive devido ao fato de que, durante as negociações de Paz em Versalhes (1919), a Organização Sionista Mundial ter ambicionado um traçado diferente do que resultou para seu território, conforme nos é apresentado por Brichs:

Los primeros proyectos de la Organización Sionista Mundial ya dibujaban unas fronteras que abarcaban desde el norte del Litani hasta el este del Jordán, precisamente para conseguir el control de los recursos hídricos de la región y evitar la posible dependencia del exterior. Sin embargo, el primer mapa político de la región tras la creación del Estado de Israel no siguió el trazado de las aspiraciones sionistas de principios de siglo ${ }^{17}$.

À parte a dimensão catastrófica que a 'Questão Palestina' assumiria com o posicionamento britânico e seus difíceis encaminhamentos futuros, há de se considerar que os diversos acordos que os britânicos e franceses firmaram entre si e com as famílias influentes no Oriente Médio ajudaram a colocar fim à dominação otomana na região.

No entanto, os primeiros problemas relativos aos acordos firmados entre a Grã-Bretanha e as famílias árabes surgiram logo após o final da I Grande Guerra. Conforme Seale ${ }^{18}$ expõe, a família Hashemita, liderada pelo xarife de Meca, Hussayn, tinha a intenção de preservar para si a região conhecida como 'Grande Síria', e que englobaria os atuais Iraque, Síria, Líbano, Palestina e Península Arábica. O plano de Hussayn era que seu filho Faysal assumisse o reinado da Síria, Ali sucedesse o pai no Reinado de Hejaz e Abdullah se tornasse Rei do Iraque. A partir daí estabelecer-se-ia o domínio Hashemita sob o mundo árabe.

Os britânicos, partindo do pressuposto de que necessitariam criar alianças no mundo árabe para sustentar sua dominação na região, não se impuseram à proposta de Hussayn e prometeram a Síria para que Faysal estabelecesse seu reinado. Satisfeito com a tratativa, Hussayn indicou seu filho, Faysal, para marchar ao lado dos britânicos nos combates ao exército otomano - aliado da Alemanha. Os britânicos, independentemente do que haviam acertado com a França no Acordo Sykes-Picot, cederam a Síria a Faysal. Os franceses, por sua vez, se opuseram enfaticamente à negociação britânica e partiram para o enfrentamento militar com o intuito de restabelecer o que havia sido acertado em 1916. Devido ao poderio bélico francês, o reinado de Faysal teve a breve duração de 18 meses, de 1918 a 1920, quando 
ocorreu sua expulsão de Damasco.

A tensão entre os britânicos e a família Hashemita assumiu grandes proporções e a Inglaterra foi obrigada a contornar o problema oferecendo o Iraque a Faysal. Ele, não tendo condições de enfrentar o exército francês sem o auxílio britânico, aceitou a proposta e, em seguida, lhe foi conferido o título de rei do Iraque. Contudo, ainda, segundo Seale ${ }^{19}$, não foi uma solução que satisfez a todos, haja vista ter gerado o ressentimento por parte de Hussayn que acabou tendo um problema com seu segundo filho, que deveria assumir o reinado do Iraque - e também com Faysal, que sentiu-se traído por não ter conseguido estabelecer seu reinado em Damasco. Um dos reflexos diretos do imbróglio britânico foi o surgimento de Faysal como uma liderança panarabista, movimento esse que geraria muitas transformações no cenário árabe do início do século XX e alcançaria uma nova fase durante o governo de Nasser, no Egito, na década de 1950. Também, evidenciou-se a fragilidade do tipo de aliança firmada entre as potências europeias e as lideranças árabes. Os árabes, de certo modo, perceberam que o tipo de vínculo que poderia ser criado com as potências estaria pautado pelo pragmatismo e que a inserção dos novos Estados ao sistema internacional seguiria a lógica da estrutura anárquica $^{20}$ inclusive com a assimetria de poder, característica essa que não confere, de fato, igualdade aos atores.

\section{A ATUAÇÃO IMPERIALISTA DAS POTÊNCIAS NO ORIENTE MÉDIO}

A atuação dos franceses na região de Mandato visava cercear quaisquer possibilidades de sublevação local e, para tanto, designou-se um Alto Comissariado para a Síria (abrangendo o Monte Líbano) e a região do Levante que alinhasse, em seu discurso, dois pressupostos, quais sejam, o fim da opressão do Império Otomano e a generosidade da libertadora França. Como parte dessa retórica imperialista, o general Henri Gouraud, fez sua famosa proclamação de amizade para com o povo libanês, ressaltando as virtudes e ideais franceses de liberdade.

At the foot of these majestic mountains, which have been the strength of your country, and remain the impregnable stronghold of its faith a freedom; on the shore of this sea of many legends that has seen the triremes of Phoenicia, Greece and Rome and now by a happy fate, brings you confirmation of a great and ancient friendship and the blessings of French peace, I solemnly salute Grand Liban, in its glory and prosperity, in the name of the Government of the French Republic ${ }^{21}$.

Num Segundo momento, devido à situação precária encontrada pelos 
franceses - considerando os embates que ocorreram com os otomanos pela administração da região -, deu-se início ao processo de estruturação do Estado nos moldes europeus, contudo, subtraindo o princípio da soberania plena, que era a base fundante do modelo de sistema internacional adotado pós-Vestefália - a França manteve sob seu controle as Forças Armadas e as Relações Exteriores. Os franceses, da mesma maneira que os ingleses, pretendiam implantar na região o modelo de Estado cliente, submisso aos interesses geopolíticos e geoeconômicos da matriz - neste caso, os detentores do Mandato. Para tanto, missões religiosas cristãs foram designadas para a região, assim como hospitais, escolas e orfanatos passaram a ser construídos. Colocava-se em prática a ocidentalização do Oriente Médio.

Concluindo a etapa para a formalização do domínio francês sob o Líbano, mais dois eventos foram marcantes. O primeiro foi a Conferência de San Remo, Itália, em 1920 que contou com a presença dos Aliados. Ali houve a ratificação do que havia sido acordado em 1916, pelo Sykes-Picot. Mas a Conferência foi além e estabeleceu a divisão física entre o Monte Líbano e a Síria, fato que gerou repúdio de parte das populações síria e libanesa que se percebiam como una.

O segundo evento que pode ser considerado paradigmático para a efetivação do Mandato deu-se em 1923, na ocasião a Liga das Nações formalizou o que fora acordado em 1916. O documento apresentava características peculiares e contraditórias. Ao mesmo tempo em que defendia o direito de "autodeterminação dos povos" também restringia a liberdade dos árabes, limitando-os política e administrativamente. Considerava-se que algumas populações encontravam-se em nível de desenvolvimento inferior, por isso precisavam da tutela de um Estado desenvolvido. Não estabeleciam por quanto tempo o Mandato transcorreria e tampouco quais seriam os critérios para a emancipação dos recém-criados Estados. Em seu artigo 22, a Convenção da Liga das Nações expressava:

[...] Certas comunidades que outrora pertenciam ao Império Otomano, atingiram tal grau de desenvolvimento que sua existência como nações independentes pode ser reconhecida provisoriamente, com a condição que os conselhos e o auxílio de um mandatário guiem sua administração até o momento em que forem capazes de se conduzirem sozinhas. Os desejos dessas comunidades devem ser tomados em primeiro lugar em consideração para escolha do mandatário ${ }^{22}$.

Neste cenário, o surgimento do Estado libanês preponderantemente cristão, numa região cercada de países árabes muçulmanos, não se apresentava como algo facilmente aceito pelos vizinhos. Por um lado, continuava 
havendo a demanda entre Líbano e Síria, onde partidários da unificação, e consequentemente do nacionalismo árabe, tinham dificuldade em aceitar a supremacia maronita na região. Por outro lado, cada vez mais a identidade nacional libanesa passava a existir, provocando preocupação aos franceses que não pretendiam que a província se tornasse plenamente independente.

Em outras localidades do mandato britânico a situação também era de difícil controle, principalmente na Palestina. A presença cada ver maior de imigrantes judeus começou a gerar preocupação por parte dos árabes que viviam naquela localidade. Ali, muito mais complexo do que o embate entre o pan-arabismo e o nacionalismo libanês, que transcorria no Líbano, o estabelecimento de qualquer arranjo que viesse a criar um Estado para um povo (judeu) em um território que já era ocupado por outro (árabe palestino) se apresentava como um desafio de difícil transposição.

Nesse sentido, a ingerência britânica sob a região fez com que o período que antecedeu à criação do Estado de Israel (1948) houvesse alternância de embates entre os grupos demandantes pelo território palestino. Britânicos apoiavam judeus, posteriormente apoiaram palestinos, e, na sequência, lutaram contra os dois. Apesar desta inconstância, politicamente o Movimento Sionista se articulava internacionalmente junto às potências no intuito de que seu projeto viesse a ser implementado. Situação diametralmente oposta viviam os palestinos com a crescente migração de judeus para a Palestina, principalmente a partir da década de 1930, quando ocorre a ascensão do Nazismo na Alemanha e o consequente antissemitismo.

Sem condições para determinar os desígnios dos povos da Palestina, ainda mais no pós-II Guerra Mundial, quando os britânicos, apesar de vitoriosos, já tinham sido superados pela nova potência ocidental que surgira - os Estados Unidos -, a solução encontrada foi entregar à recém criada Organização das Nações Unidas (ONU) a incumbência de deliberar sobre o futuro de judeus e palestinos.

Cabe ressalvar que a estrutura do sistema internacional já havia sido alterada no final da II Guerra Mundial e a multipolaridade que, de certo modo, havia ajudado a tensionar as potências europeias e desencadeado a guerra - ainda mais se considerar o fato de que o modelo proposto de Segurança Coletiva $^{23}$ não surtira efeito -, cedeu lugar à bipolaridade. Gradualmente, Estados Unidos e União Soviética passaram a disputar a hegemonia mundial e o reflexo no Oriente Médio foi imediato.

Inclusive, a própria decisão de criar um Estado judaico na Palestina estava envolto na nova estrutura de poder que o sistema internacional vivenciava, pois, apesar de a deliberação ter sido oriunda de uma organização internacional que visava comportar o entendimento da coletividade das nações, a supremacia estadunidense era flagrante. Com vista a este fato, a criação do Estado de Israel somente foi possível porque o presidente dos EUA, 
Harry Truman, se empenhou pessoalmente neste episódio e desconsiderou os interesses dos árabes, diretamente afetados.

The UN resolved in November 1947 to partition Palestine into two states. The six Arab members of the United Nations (Egypt, Lebanon, Saudi Arabia, and Syria were founding members of the UN; Iraq joined in December 1945 and Yemen in 1947) all apposed partition, but had no impact on the debate within the General Assembly. They failed to build a coalition of nations to support Arab claims to Palestine and were outmanoeuvred by the Jewish Agency. The final vote in General Assembly was thirtythree to thirteen, giving the necessary two-thirds majority to ensure the passing of the Partition Resolution ${ }^{24}$.

Se, durante o século XIX, as potências europeias aturam com certa ponderação junto ao Império Otomano, e, no início do século XX buscavam pautar suas ações em mecanismos que pudessem legitimar seus atos, com o final da II Guerra Mundial houve uma mudança radical de cenário. O Oriente Médio, já configurado a partir dos interesses externos, se tornou o palco ideal para os embates entre as duas potências que surgiram no pós-II Guerra Mundial. As questões geopolítica e geoeconômica ganharam prioridade, no entanto, a transposição do modelo estadocêntrico europeu para o mundo muçulmano médio-oriental não foi tão simples. Se, durante o século XIX, as potências europeias aturam com certa ponderação junto ao Império Otomano, e, no início do século XX buscavam pautar suas ações em mecanismos que pudessem legitimar seus atos, com o final da II Guerra Mundial houve uma mudança radical de cenário. O Oriente Médio, já configurado a partir dos interesses externos, se tornou o palco ideal para os embates entre as duas potências que surgiram no pós-II Guerra Mundial. As questões geopolítica e geoeconômica ganharam prioridade, no entanto, a transposição do modelo estadocêntrico europeu para o mundo muçulmano médio-oriental não foi tão simples.

\section{O TABULEIRO DO JOGO DO PODER NO CENÁRIO INTERNACIONAL}

De certo modo, tanto França quanto Grã-Bretanha alcançaram seus objetivos iniciais, no que tange ao Império Otomano, pois conseguiram anular um grande ator que poderia ameaçar as duas potências da época. Ainda, com a aliança formalizada entre otomanos e alemães, conjunturalmente a situação se tornou ainda mais favorável, pois com o final da I Guerra Mundial houve a anulação do inimigo germânico que provocava certo desequilíbrio na balança de poder da Europa. 
Outro aspecto também merece destaque, pois as potências europeias do século XIX atuavam a partir de estratégias fundamentadas nos princípios ratzelianos, ou seja, ratificando a máxima de que o poder estaria vinculado à dimensão territorial. Nesse sentido, o modelo colonialista se justificaria como uma ação natural do Estado. É certo que as teorias de Ratzel, sob muitos aspectos, vieram a ser contestadas, contudo, naquele momento histórico se adequavam à forma de atuar das potências. Desse modo, a expansão para o Oriente Médio se dava de modo natural e necessária, isso é, adotando-se a perspectiva do lebensraum (espaço vital) ${ }^{25}$.

No entanto, ao aceitar estes pressupostos da prática do Estado potência frente aos demais, acaba-se naturalizando o processo de dominação de outros povos e, por conseguinte, retirando as intenções imperialistas de seus governantes ${ }^{26}$, fato esse que não pode ser desconsiderado sem a devida ressalva. Contudo, em certa medida, como as Escolas de Relações Internacionais tendem a utilizar como referencial principal o Estado, independentemente do tipo de governo e quem o governe, a perspectiva estadocêntrica, aplicada neste caso, poderia responder ao porquê de França e Inglaterra terem expandido seu poder para a região do Oriente Médio.

Como exposto anteriormente, a estrutura multipolar do sistema internacional, que perdurou de 1815 até o início da I Guerra Mundial, gerava tensionamento entre os Estados, haja vista suas capacidades serem similares, no entanto, havia insegurança acerca de possíveis desequilíbrios neste equacionamento. O Equilíbrio de Poder, desse modo, foi o responsável, em grande medida, pela paz relativa que perdurou por quase 100 anos, no entanto, esta mesma insegurança e necessidade de se proteger dos demais atores fez com que houvesse o desencadeamento da I Guerra Mundial ${ }^{27}$.

Partindo, ainda, do pressuposto trazido por Mackinder no início do século XX de que

[...] De hoje em diante, na idade pós-Colombina, devemos novamente ter de lidar com um sistema político fechado, e no entanto será um de escopo mundial. Toda explosão de forças sociais, no lugar de ser dissipada em um circuito ao redor, de espaço desconhecido e caos bárbaro, será fortemente reecoada desde as longínquas partes do globo, e por isso os fracos elementos no organismo político e econômico do mundo serão em consequência destroçados ${ }^{28}$.

as atuações francesa e inglesa junto ao Império Otomano poderiam se configurar num ato de poder imperialista, mas embasados numa preocupação de segurança, haja vista a desconstrução do Império ser algo flagrante e a necessidade de reestruturação de forças na região dar-se-ia como elemento 
primordial para a manutenção do status quo de potência.

Assim, o Oriente Médio deixou de ser uma região de interesse assessório para ganhar status de prioritário. A fragilização do Império Otomano, como tratado anteriormente, contou com ações internas e externas, inclusive, a prática das potências europeias de infiltrarem-se em determinadas regiões otomanas para promover o comércio ou mesmo para a difusão de ideologias advindas de seu continente contribuiu para o fomento do nacionalismo árabe e outros ${ }^{29}$.

Isso posto, o Oriente Médio passou a ganhar ênfase na Agenda da política externa das potências, como ficou evidenciado ao debaterem e criarem normatizações para o exercício do poder na região - através de acordos e tratados. No entanto, o referencial principal para a reorganização do sistema internacional já estava pautado pela lógica estadocêntrica, e, desse modo, a constituição de Estados artificiais nas ex-possessões otomanas apresentava-se como algo natural, tendo em vista que o padrão estabelecido para as interrelações era Estado-Estado.

Cabia, no entanto, regular o tipo de Estado que seria constituído e o grau de autonomia que seria dado a ele. Com isso, a opção por segmentar o território otomano de modo a reduzir o potencial aglutinador da religião islâmica configurava-se com necessário para efetivar a dominação. Daí a estratégia de criação de um Estado libanês cuja comunidade cristã maronita exerceria grande poder e da criação do Estado de Israel para os judeus.

Assim, com base no entendimento acerca da estrutura do sistema internacional reinante no momento, as potências europeias preservariam seu status quo com a expansão da zona de influência sob o Oriente Médio, porém, desde que estabelecido o modelo estadocêntrico vestefaliano no qual conseguiam exercer o domínio sob os Estados clientes que dali surgissem. Contudo, as transformações oriundas do final da II Guerra Mundial colocaram em xeque a capacidade de França e Inglaterra continuarem regendo o sistema internacional e o resultado desse processo foi a substituição destas lideranças pelas duas novas potências, EUA e URSS, que arcariam com os desdobramentos do processo de estatização do Oriente Médio.

\section{O ESTADOCENTRISMO FALHOU}

Após a II Guerra Mundial a bipolaridade do sistema internacional foi estabelecida com a preponderância de Estados Unidos e União Soviética com superpotências. Tal característica foi acentuada com as diferenças ideológicas e o desenvolvimento das armas nucleares por parte dos dois atores. E, nesse cenário, a Escola de Relações Internacionais que ganhou supremacia foi a Realista, cuja unidade de análise prioriza o Estado.

Os realistas são os teóricos do estado da guerra. Por ser 
anárquico, o sistema internacional é baseado no poder e na força, com os Estados vivendo numa situação caracterizada pelo contexto da insegurança recíproca. Neste contexto, as variações nos objetos e no poder de cada um os torna passíveis de se transformarem em adversários e a terminarem resolvendo os seus conflitos através da guerra ${ }^{30}$.

Em consequência da bipolaridade do cenário internacional, as políticas externadas das superpotências construíram suas estratégias considerando o Estado como unidade básica de interação, haja vista não entenderem como relevantes outros tipos de atores não-estatais. Também, a importância geoeconômica que o Oriente Médio assumiu, tendo vista suas reservadas de petróleo, fez com que tanto estadunidenses quanto soviéticos disputassem a influência sob a região ${ }^{31}$. Assim, se a partir da década de 1940 os Estados sob Mandato passaram a alcançar sua independência, de fato, esta autonomia não chegou a se concretizar plenamente, uma vez que a atuação das superpotências, de modo direto ou indireto, passou a influir na região.

Mesmo com os desafios trazidos à tona pelas alterações no sistema internacional, sua bipolaridade fez com que o equilíbrio de forças estabelecido por União Soviética e Estados Unidos reiterassem a importância do Estado como ator principal. E, ainda que tenha havido a flexibilização de alguns pressupostos realistas e liberais com a inserção do sufixo "neo" às teorias, a arena internacional tendia a relativizar a importância de outros atores nãoestatais, fato esse que reiterava a necessidade de estruturar o Oriente Médio a partir do modelo estadocêntrico e desconsiderar outros atores regionais.

Como exposto anteriormente, a criação do Estado de Israel atendia aos interesses dos Estados Unidos, tendo em vista que proporcionaria a existência de um enclave ocidental em meio à população predominantemente muçulmana. Porém, o nível de rejeição que tal ato assumiu fez com que ocorressem duas reações simultaneamente, quais sejam, 1) uma potencial unificação dos interesses árabes contra o Estado judeu - gerando desde a guerra da independência de Israel, em 1948, até os conflitos de 1956, 1967 e 1973 -; e, 2) a impossibilidade de concretizar a divisão da Palestina no formato de Estado, como a Resolução 181 da ONU designava - o que futuramente acarretou a criação da Organização para a Libertação da Palestina (OLP) para lutar contra o Estado de Israel, e, consequentemente, as Intifadas e demais conflitos pela posse dos territórios palestinos ocupados pelos israelenses desde 1947. A lógica estadocêntrica da Escola Realista das RI se abalava, pois não mais conseguia responder à nova lógica que o sistema internacional vivenciava com a atuação de organizações não-estatais que tinham o poder de influir nos temas internacionais.

De modo pragmático, o Estado de Israel continua atuando como um 
fator desestabilizante da região, pois apesar de sua criação ter sido oriunda de um ato das ONU, não permite que um Estado Palestino seja criado às suas fronteiras. E mais, gradualmente amplia seu território e ocupa áreas predominantemente palestinas. Como é interessante para os Estados Unidos manterem seu enclave no Oriente Médio, por uma questão iminentemente geopolítica, aceitam esta forma de atuar israelense ${ }^{32}$. O resultado direto desta ação é a existência de uma grande população palestina vivendo no exílio em vários países do Oriente Médio e em outras localidades no mundo. Da Palestina ocupam somente a Faixa de Gaza e Cisjordânia, contudo sem status de Estado.

Ainda, no que tange ao Líbano e a Síria, a divisão formalizada em 1943, a partir das delimitações territoriais estabelecidas pelo franceses, não atendeu à demanda de grande parte da comunidade islâmica dos dois países, fato que gerou tensões internas no Líbano e uma catastrófica guerra civil no país - de 1975 a 1990. Nesse evento, ainda houve a participação da Síria, a partir de 1976, e, posteriormente, a partir de 1978, do Estado de Israel. Se a criação do Estado libanês já se configurava em algo de difícil concretização, haja vista absorver quase duas dezenas de grupos religiosos distintos e a divisão de poder estar fundamentada em um modelo confessional estabelecido pelo Pacto Nacional (1943) que tornou-se fortemente questionável com o passar dos anos, a inserção de atores estrangeiros aos problemas internos somente fragmentou ainda mais a frágil unidade nacional ${ }^{33}$.

Com isso, o final do Sistema de Mandato não significou a efetivação do modelo de Estados para a região. Seja pela delimitação territorial que nunca atendeu aos interesses das comunidades locais - mas, sim, das potências imperialistas -, ou mesmo pela diferença de assimilação do nacionalismo que surgiu com características localizadas, como o "libanismo", mas também na forma do pan-arabismo e do pan-islamismo. E mais tarde na vertente religiosa do islamismo, ou fundamentalismo islâmico.

O Iraque também é um exemplo da dificuldade de assimilação do modelo de Estado nacional proposto pelo Ocidente, tendo em vista que sua população é formada prioritariamente por três grupos, quais sejam, sunitas, curdos e xiitas, contudo o domínio sunita perdurou, apesar de não ser o grupo numericamente mais expressivo da população. Ainda, apesar de o ano de 1932 datar sua independência da Grã-Bretanha, de fato, os ingleses não deixaram de influir no Iraque, exceto quando foram substituídos pelos estadunidenses. Neste caso, as imensas reservas de petróleo iraquiano foram preponderantes para a decisão estadunidense de manter a dominação local; também tiveram forte peso na decisão de desencadear guerras contra o Irã (1980-88), ao lado do Kuwait (1990-91) ou para a destituição de Saddam Hussein (2003) ${ }^{35}$.

O país da região que melhor assimilou o conceito de Estado nacional foi a Turquia, e, isso foi possível devido às medidas político-econômicas e 
sociais implantadas por Ataturk, a partir da década de 1920, nas quais tentava suprimir elementos islâmicos da cultura local. O resultado foi um processo de "ocidentalização" do país e criação de ferramentas institucionais para bloquear o crescimento de movimentos religiosos que, por ventura, quisessem islamizar a política turca - inclusive com o implemento de políticas de segurança severas e limitação de atuação de determinadas organizações. A tão almejada adesão à União Europeia (UE) também é um fator que faz com que se busque preservar as características ocidentais do Estado, apesar de esta possível abertura da Europa para a Turquia ser vista pela grande maioria dos estadistas europeus como um grande risco, uma vez que poderia alterar a "identidade europeia" com a entrada de muçulmanos.

Apesar dos conflitos internos vivenciados pelos países do Oriente Médio e que afetavam suas estruturas político-econômicas, as superpotências sempre estiveram mais preocupadas com a preservação de um governo nacional que pudesse atuar a partir de seus interesses. Para tanto, torna-se irrelevante qualquer caráter democrático ou mesmo viés religioso, haja vista ao mesmo tempo em que os Estados Unidos mantinham - com alguns ainda mantém - relações políticas com a Arábia Saudita - wahhabita, vertente islamista do Islã sunita - também estavam próximos de Saddam Hussein governante iraquiano sunita e secular -, do Xá Reza Pahlavi - rei xiita do Irã até 1979 -, e, do governo turco - forte aliado na política de contenção do comunismo soviético durante a Guerra Fria. Quanto à influência soviética, a questão ideológica não era o fator principal para o estabelecimento de aliança, haja vista ter sob sua órbita tanto Síria quanto Egito, que dispunham de governos cuja ideologia - se é que adotavam alguma em particular - não se encaixava no modelo socialista da URSS. Ou seja, tanto para estadunidenses quanto para soviéticos, o pragmatismo era o que imperava nas relações com os Estados médio-orientais.

Considerando a perspectiva teórica de Waltz, que privilegia a atuação das superpotências e enfatiza que o modelo bipolar do sistema internacional proporciona maior estabilidade, ainda mais com a variável das armas nucleares como balizador e bloqueador de embates diretos, o nível de análise das Relações Internacionais cada vez mais enfatizou o Estado e deu menos importância a questões de ordem interna. Assim, apesar de o Oriente Médio se configurar como uma região de suma importância para Estados Unidos e União Soviética, deixou-se de considerar aspectos internos e desestabilizantes relacionados à intervenção executada no naquela região e que a transformou num mosaico de etnias, religiões e nacionalismos. O resultado é a dificuldade de se convergir para a construção do modelo de Estado nacional proposto pelas potências europeias e sedimentado pelo sistema internacional.

Tal é a dificuldade de conformar os valores islâmicos ao modelo de Estado nacional que as correntes islamistas que rejeitavam o secularismo, 
a partir da década de 1980 passaram a ganhar força através da atuação de grupos como Hezbollah, Hamas, al-Qaeda, dentre outros. Estas organizações visavam, muito além de confrontar valores ocidentais, restaurar a ummah. Contudo, em que pese a crítica de que grande parte da comunidade islâmica já assimilou os valores ocidentais ou mesmo conseguiu encontrar um meio termo entre Islã e secularismo, uma parcela substancial de muçulmanos que vive no Oriente Médio não percebe avanços na estrutura estadocêntrica ali instaurada, haja vista a autonomia ser restrita devido aos interesses geopolíticos das potências. Evidentemente que a não concordância com a divisão territorial do estados do Oriente Médio implicaria na rejeição do modelo estadocêntrico, no entanto, como a soberania, que é o valor que pauta o sistema internacional desde Vestefália, nunca foi aplicada em sua plenitude para os povos do Oriente Médio, esta estrutura organizacional acaba ganhando contornos de questionamentos mais profundos oriundos de outras Escolas das RI.

Nesse sentido, o paradigma que foi criado pelos Realistas para compreender as Relações Internacionais e que foi aplicado sem críticas pelas potências, vive um momento de profunda reavaliação, uma vez que a organização político-administrativa do Oriente Médio não encontra estabilidade. Seja pela atuação de organizações islamistas que contestam a maneira com que o Ocidente atua em território islâmico ou mesmo pela insatisfação de secularistas que veem sua liberdade restrita por interesses externos, o modelo estadocêntrico entra em colapso no Iraque - com a atuação do Islamic State of Iraq and the Levant (ISIL) -, na Síria - pela guerra civil que se alastra desde 2011 e atuação do ISIL - ou mesmo em outros Estados desestabilizados pela insatisfação dos resultados obtidos com a Primavera Árabe.

Se, desde o início do século XX as potências ocidentais passaram a atuar com mais ênfase no Oriente Médio e as Relações Internacionais simplesmente utilizaram os pressupostos ocidentais para criarem uma teorização que desprezava as particularidades da cultura islâmica, em detrimento de uma lógica de poder, o estado que o Oriente Médio se encontra atualmente acaba sendo facilmente compreensível. As teorias de poder simplesmente trataram o Oriente Médio como um objeto e, nesse sentido, tentaram construí-lo à luz das proposições que conseguissem submetê-lo à dominação das potências. Daí a necessidade de criação de Estados no território otomano, de estabelecer governos e de propiciar relações diplomáticas - em nível de desigualdade, evidentemente. Tudo a partir de um modelo já conhecido e controlado pela burocracia estatal das potências europeias.

No entanto, à desestabilidade existente no Oriente Médio nos dias atuais, o questionamento maior que se deve fazer diz respeito à estrutura que foi constituído e se é possível preservá-la como está. Em vista da fragmentação dos Estados atuais, a possibilidade que surge de redimensionamento destes 
estados para atender aos interesses de suas comunidades e não das potências, acaba sendo uma possibilidade de difícil configuração, haja vista a região ainda ser de interesse econômico das potências.

Nesse sentido, não há qualquer medida viável para ser empregada no intuito de encerrar os conflitos e reconstruir o Oriente Médio, apenas poderão ser propostas medidas paliativas que busquem reforçar o modelo estadocêntrico na região e as organizações islamistas, mesmo aquelas que não propõem qualquer tipo de ação armada para desestruturar o Estado, continuarão à margem de qualquer processo democrático - como ocorreu no Egito com a Irmandade Muçulmana que, mesmo vencendo o pleito eleitoral foi extirpada do governo. Assim, qualquer que seja o novo desenho do Oriente Médio, os conflitos continuarão latentes e na iminência de serem revitalizados. Com isso, é indubitável que o Oriente Médio continuará sendo objeto das Relações Internacionais, alcançando o interesse de todos os atores que busquem a preponderância no sistema internacional, independentemente da atuação dos movimentos islamistas e dos inúmeros massacres que possam vir a acontecer na região.

\section{NOTAS}

${ }^{1}$ Apesar da adoção desta premissa, alguns autores, como Krasner, entendem que as potência, apesar de defenderem Vestefália, sempre violaram a soberania de outros Estados de acordo com seus interesses. Cf.: KRASNER, Stephen. Compromising Westphalia. In: International Security, vol. 20, 1995, p. 115-151.

${ }^{2}$ ESPOSITO, John L. Islam, the Straight Path. New York: Oxford University Press, 2005.

${ }^{3}$ FROMKIN, David. Paz e Guerra no Oriente Médio - A Queda do Império Otomano e a Criação do Oriente Médio Moderno. Rio de Janeiro: Ed. Contraponto, 2008, p. 40.

${ }^{4}$ HOURANI, Albert. O Pensamento árabe na era liberal, 1798-1939. São Paulo: Companhia das Letras, 2005, p. 124.

${ }^{5}$ Pensador sírio da segunda metade do século XIX e início do XX, sua obra ganhou relevância ao propagar o pan-arabismo num momento em que o sultanato vivenciava a tensão entre turcos e árabes pela supremacia no Islã.

${ }^{6}$ HOURANI, op. cit. p. 287.

${ }^{7}$ Ibidem. p. 296.

${ }^{8}$ COLLELO, Thomas (Ed.). Lebanon - A Country Study. Federal Research Division Library of Congress (1989). Disponível em: < http://memory.loc.gov/cgi-bin/query/r?frd/cstdy:@ field(DOCID+lb0027)>

${ }^{9}$ De acordo com Waltz, a balança de poderes se dá devido ao fato de que os Estados são atores unitários que procuram, no mínimo, a sobrevivência física e, no máximo, se possível, controlar outros Estados. Com isso, seus objetivos são prosseguidos por ações internas e externas. Ainda considerando o fato de que os Estados agem num sistema de autoajuda e sem árbitro, aqueles que não potenciam as suas capacidades ficam fragilizados em relação aos adversários. Assim, a balança de poderes estaria enraizada na própria estrutura do sistema internacional dos Estados. 
Cf.: WALTZ, Kenneth N. Theory of International Politics. Long Grove, IL: Waveland Pr Inc, 2010 .

${ }^{10}$ O Acordo somente veio à tona após a Revolução Russa (1917), quando os bolcheviques publicaram documentos diplomáticos secretos nos quais a Rússia havia tomado parte.

11 ACORDO SYKES-PICOT (1916), disponível em: <http://unispal.un.org/UNISPAL. NSF/0/232358BACBEB7B55852571100078477C>

${ }^{12}$ SALIBI, Kamal. A House of Many Mansions - The History of Lebanon. California: University of California Press, 1988, p. 21.

${ }^{13}$ Ibidem. p. 27.

${ }^{14}$ Ibidem. p. 32.

${ }^{15}$ HOURANI, Albert. Uma história dos Povos Árabes. $2^{\text {a }}$ edição, São Paulo: Cia das Letras, 2001, p. 321.

16 COHN-SHERBOK, Dan; EL-ALAMI, Dawoud. O Conflito Israel-Palestina. Editora Palíndromo, 2005, p. 133.

17 BRICHS, Ferran Izquierdo. Guerra y Agua: Objetivos y Actitudes de los Actores en el Conflicto por Palestina. [Tese] Departamento de Directo Publico y Ciencias Histórico-Jurídicas da Universidad Autónoma de Barcelona, Julio/2002, p. 358.

${ }^{18}$ SEALE, Patrick. The struggle for Syria. A study of post-war Arab politics 1945-1958. London: Oxford University Press, 1966.

${ }^{19}$ Ibidem.

${ }^{20}$ Uma das bases fundantes dos Estudos de Relações Internacionais é a adoção do entendimento de que o sistema internacional é anárquico e, por isso, os Estados são iguais. Em tese esta estrutura é possível porque estaria assegurada a soberania de cada país, conforme estabeleceu a Paz de Vestefália, no entanto, a estrutura anárquica não iguala os Estados de fato, haja vista suas capacidades serem distintas e a ausência de uma estrutura supranacional que possa estabelecer regramentos fazer com que Estados menos poderoso se submetam aos mais poderosos. Várias Escolas de RI adotam a estrutura anárquica como paradigma de sistema internacional, e esta proposição é fundamental para o Realismo e, consequentemente, para o entendimento de como os atores se comportavam durante a Guerra Fria.

${ }^{21}$ Disponível em: < http://www.kfs10.com.br/loubnan/leb1.htm>

${ }^{22}$ Disponível em: < http://www.dhnet.org.br/direitos/anthist/his1919.htm>

23 “A doutrina de segurança coletiva foi materializada no Pacto da Liga das Nações, o qual, por sua vez, fazia parte dos tratados que puseram fim à Primeira Guerra Mundial. Diversos dos artigos do Pacto da Liga das Nações eram especialmente dignos de nota. No Artigo 10, qualquer guerra ou ameaça de guerra eram declaradas como uma preocupação de rodos os estados. Nos Artigos 12 e 15, os estados concordavam em submeter suas divergências à arbitragem e não ir à guerra antes de três meses após o fracasso da arbitragem. O Artigo 16, o artigo decisivo, afirmava que qualquer guerra contrária aos procedimentos da Liga das Nações seria considerada uma declaração de guerra contra todos os membros da Liga das Nações. O estado que começasse uma guerra estaria imediatamente sujeito a sanções econômicas e o Conselho da Liga poderia recomendar medidas militares adicionais". In: NYE JR., Joseph S. Cooperação e Conflito nas Relações Internacionais. São Paulo: Editora Gente, 2009, p. 109-110.

${ }^{24}$ HUREWITZ, 1976 apud ROGAN, Eugene L. The Emergence of the Middle East into the Modern System. In FAWCETT, Louise (org.). International Relations of the Middle East. 
Oxford: Oxford University Press, 2009, p. 40.

25 “[...] necessidade territorial de uma sociedade tendo em vista seu equipamento tecnológico, seu efetivo demográfico, e seus recursos naturais disponíveis. Seria assim uma relação de equilíbrio entre a população e os recursos, mediada pela capacidade técnica. Seria a porção do planeta necessária para a reprodução de uma dada comunidade" In: MORAES, Antonio Carlos Robert. Ratzel. São Paulo: Editora Ática, 1990, p. 23.

${ }^{26}$ Esta argumentação foi contestada mesmo dentro da Geografia, por Yves Lacoste, que expôs que as Ciências não seriam isentas e que a "condenação" da Geopolítica como "instrumento nazista" teria sido um ato ideológico, pois todos as demais Ciências também foram utilizadas, de alguma forma e em algum grau, como instrumento de poder. Ainda, no que tange à prática do colonialismo, Edward Said expõe em suas obras Orientalismo (1978) e Cultura e Imperialismo (1993) que não se configurava em um ato "natural", mas sim que buscava-se "naturalizar" o processo de submissão de alguns povos aos europeus.

${ }^{27}$ NYE JR., Joseph S. Cooperação e Conflito nas Relações Internacionais. São Paulo: Editora Gente, 2009.

${ }^{28}$ MACKINDER, Halford J. O Pivô Geográfico da História. Tradução Fabrício Vasselai. In: GEOUSP - Tempo e Espaço, nr. 29, 2011, p. 87.

${ }^{29}$ HOBSBAWN, Eric J. Nações e Nacionalismos desde 1780. Rio de Janeiro: Ed. Paz e Terra, 2002.

${ }^{30}$ OLIVEIRA, Flávio Rocha. O Realismo Político. In NEVES, André Luiz Varella (org.). Teoria das Relações Internacionais - As Questões Mundiais em Debate. Petrópolis, RJ: Editora Vozes, 2014, p. 74.

${ }^{31}$ FUSER, Igor. Petróleo e Poder: o Envolvimento Militar dos Estados Unidos no Golfo Pérsico. São Paulo: Ed. UNESP, 2008.

${ }^{32}$ Mearsheimer e Walt analisam a relação entre Israel e EUA a partir da atuação do Lobby Israelense no Congresso dos EUA. De certo modo, os autores conseguem estabelecer esta conexão a partir da conjunção de interesses mútuos, no entanto, ainda ressaltam que em determinadas situações a prevalência dos interesses israelense sobre os estadunidense amplia a dimensão dos conflitos na região do Oriente Médio e reforça o sentimento de antiamericanismo no mundo, mais particularmente no mundo árabe e muçulmano. Para uma análise mais aprofundada sobre o tema, ver: MEARSHEIMER, John J.; WALT, Stephen M. O Lobby de Israel. In: Novos Estudos 76, CEBRAP, novembro 2006, pp. 43-73.

${ }^{33}$ FISK, Robert. Pity the Nation - Lebanon at War. Oxford: Oxford University Press, 2001.

${ }^{34}$ KEEGAN, John. A Guerra do Iraque. Rio de Janeiro: Biblioteca do Exército Editora, 2005.

${ }^{35} \mathrm{O}$ islamismo, ou fundamentalismo islâmico, surge durante o século XVIII com o wahhabismo, no entanto, no início do século XX, no Egito, Hassan al-Banna e, posteriormente, Sayyd Qutb estruturaram a Irmandade Muçulmana a partir de princípios que visam restaurar os valores islâmicos. Outros teorizadores também criaram segmentos do que viria a ser o movimento islamista em diversas localidades islâmica e não apenas no Oriente Médio, deles surgiram diversas organizações que passaram a atuar contra o Ocidente ou lideranças políticas islâmicas alinhadas às potências.

Artigo recebido em janeiro de 2015. Aceito em setembro de 2015. 